\title{
Synthesis of Multicolor Core/Shell
} $\mathrm{NaLuF}_{4}: \mathrm{Yb}^{3+} / \mathrm{Ln}^{3+} @ \mathrm{CaF}_{2}$ Upconversion Nanocrystals

\author{
Hui Li ${ }^{1}$, Shuwei Hao ${ }^{1, *}$, Chunhui Yang ${ }^{1}$ and Guanying Chen ${ }^{1,2, *}$ \\ 1 MIIT Key Laboratory of Critical Materials Technology for New Energy Conversion and Storage, \\ School of Chemistry and Chemical Engineering \& Key Laboratory of Micro-systems and Micro-Structures, \\ Ministry of Education, Harbin Institute of Technology, Harbin 150001, China; huili@hit.edu.cn (H.L.); \\ yangchh@hit.edu.cn (C.Y.) \\ 2 Institute for Lasers, Photonics and Biophotonics, State University of New York at Buffalo, \\ Buffalo, NY 14260, USA \\ * Correspondence: haosw@hit.edu.cn (S.H.); chenguanying@hit.edu.cn (G.C.); \\ Tel.: +86-451-864-038-08 (S.H. \& G.C.)
}

Academic Editor: Thomas Nann Received: 20 December 2016; Accepted: 3 February 2017; Published: 7 February 2017

\begin{abstract}
The ability to synthesize high-quality hierarchical core/shell nanocrystals from an efficient host lattice is important to realize efficacious photon upconversion for applications ranging from bioimaging to solar cells. Here, we describe a strategy to fabricate multicolor core @ shell $\alpha-\mathrm{NaLuF}_{4}: \mathrm{Yb}^{3+} / \mathrm{Ln}^{3+} @ \mathrm{CaF}_{2}(\mathrm{Ln}=\mathrm{Er}, \mathrm{Ho}, \mathrm{Tm})$ upconversion nanocrystals (UCNCs) based on the newly established host lattice of sodium lutetium fluoride $\left(\mathrm{NaLuF}_{4}\right)$. We exploited the liquid-solid-solution method to synthesize the $\mathrm{NaLuF}_{4}$ core of pure cubic phase and the thermal decomposition approach to expitaxially grow the calcium fluoride $\left(\mathrm{CaF}_{2}\right)$ shell onto the core UCNCs, yielding cubic core/shell nanocrystals with a size of $15.6 \pm 1.2 \mathrm{~nm}$ (the core $\sim 9 \pm 0.9 \mathrm{~nm}$, the shell $\sim 3.3 \pm 0.3 \mathrm{~nm}$ ). We showed that those core/shell UCNCs could emit activator-defined multicolor emissions up to about 772 times more efficient than the core nanocrystals due to effective suppression of surface-related quenching effects. Our results provide a new paradigm on heterogeneous core/shell structure for enhanced multicolor upconversion photoluminescence from colloidal nanocrystals.
\end{abstract}

Keywords: core/shell nanocrystals; liquid-solid-solution method; thermal decomposition; multicolor emissions

\section{Introduction}

Upconversion nanocrystals (UCNCs) are able to convert two or more long wavelength photons into short wavelength emissions through the use of real energy levels of trivalent lanthanide ions embedded in an inorganic host lattice [1]. Owing to the high physicochemical stability and intrinsic low phonon energy, fluoride-based UCNCs are able to minimize energy losses at the intermediate states of the incorporated lanthanide ions, thus generally exhibiting efficient upconversion (UC) luminescence efficiency [2]. Moreover, fluoride UCNCs also have superior features, such as low toxicity, non-blinking, non-photobleaching, absence of autofluorescence, and tissue-penetrable near-infrared (NIR) light excitation [3,4]. These superb attributes promise their applications in biological imaging [5-8], bio-detection [9,10], and three-dimensional display [11-13]. This motivation fuels a range of works to synthesize UCNCs with controlled size and morphology, as well as to prepare epitaxial core/shell UCNCs with enhanced efficiency and multifunction for theranostic applications, such as, $\mathrm{NaYF}_{4}: \mathrm{Yb} / \mathrm{Er} @ \mathrm{NaYF}_{4}$ [14], $\left(\mathrm{NaLuF}_{4}: \mathrm{Gd}^{3+} / \mathrm{Yb}^{3+} / \mathrm{Er}^{3+}\right) @ \mathrm{NaLuF}_{4}: \mathrm{Yb}^{3+}$ [15], and $\mathrm{NaYbF}_{4}: \mathrm{Er} @ \mathrm{NaGdF}_{4}$ core/shell nanostructures [16].

Sodium lutetium fluoride $\left(\mathrm{NaLuF}_{4}\right)$ has recently emerged as a new type of efficient host lattice for photon upconversion, similar to the well-established host material of sodium yttrium fluoride 
$\left(\mathrm{NaYF}_{4}\right) . \mathrm{NaLuF}_{4}$-based UCNCs have been demonstrated to exhibit bright upconversion luminescence (UCL) [17-24] and show efficient five- and four-photon ultraviolet emissions under continuous wave excitation at $980 \mathrm{~nm}$ [25-27]. Despite recent success in synthesizing $\mathrm{NaLuF}_{4}$ nanoplates or nanorods with size over $\sim 30 \mathrm{~nm}$ using thermal decomposition method [28-31] or hydrothermal method [32-38], the ability to prepare uniform single crystal phase sub-10 nm NaLuF $\mathrm{UCNC}_{4}$ remains elusive. Moreover, doping of a high concentration of inert $\mathrm{Gd}^{3+}$ ions $(\geq 20 \%)$ was typically required to prepare small-sized monodisperse $\mathrm{NaLuF}_{4}$ UCNCs with single crystal phase previously $[17,39]$, thus delivering traits actually from an entity of Lu-Gd alloyed host. On the other hand, small-sized UCNCs are important for single molecule imaging [40] and in vivo bioimaging with reduced toxicity, considering the renal clearance [41]. However, they always come at the sacrifice of UCL efficiency due to the increased size-induced surface-related surface quenching effect [42]. A core/shell geometric structure is therefore needed to eliminate or suppress this detrimental effect by spatial isolation of the core nanoparticle from the surrounding quenching sites. A straightforward approach is to grow a homogenous core/shell structure where the host of the shell is identical to the core [37,43]. However, the possible leaking of rare earth ions from the host lattice could possibly lead to diseases such as nephrogenic systemic fibrosis [44,45]. Compared with lanthanide fluorides, calcium fluoride $\left(\mathrm{CaF}_{2}\right)$ has unique advantages owing to its superior biocompatibility and high optical transparency [46-51]. It has recently been demonstrated that $\mathrm{CaF}_{2}$ also has low lattice mismatch with $\mathrm{NaReF}_{4}$ nanocrystals, and can efficiently prevent rare-earth ions from leaking [46,50]. This implies that the growth of a $\mathrm{CaF}_{2}$ shell not only renders UCL enhancement, but also imparts biocompatibility with reduced leaking effect.

In this work, we describe our effort toward the controlled synthesis of single crystal phase sub-10 nm $\alpha-\mathrm{NaLuF}_{4}: \mathrm{Yb}^{3+} / \mathrm{Ln}^{3+}(\mathrm{Ln}=\mathrm{Er}, \mathrm{Ho}$, or $\mathrm{Tm})$ nanoparticles using a liquid-solid-solution method without the involvement of doping with a high concentration of $\mathrm{Gd}^{3+}$, and then utilize them as the core to epitaxially grow a high quality $\alpha-\mathrm{NaLuF}_{4}: \mathrm{Yb}^{3+} / \mathrm{Ln}^{3+} @ \mathrm{CaF}_{2}(\mathrm{Ln}=\mathrm{Er}, \mathrm{Ho}$, or Tm) core/shell UCNC via a thermal decomposition protocol. We found that the growth of a $\sim 3 \mathrm{~nm}$ thin $\mathrm{CaF}_{2}$ shell layer was able to enhance the multicolour UCL of the core nanocrystals by up to $\sim 772$-fold.

\section{Results and Discussion}

\subsection{Synthesis of $\alpha-N a L u F_{4}: Y^{3+} / L^{3+}(L n=E r, T m, H o)$ or $\alpha-N a L u F_{4}: Y b^{3+} / L n^{3+} @ C a F_{2}$ Core/Shell UCNCs}

The crystal structure of $\mathrm{NaLuF}_{4}$ has two forms of the cubic $(\alpha-)$ and the hexagonal ( $\left.\beta-\right)$ phase. To prepare high-quality $\alpha-\mathrm{NaLuF}_{4} @ \mathrm{CaF}_{2}$ core/shell NCs, we firstly controlled the synthesis of cubic $(\alpha) \mathrm{NaLuF}_{4}$ core nanoparticles by varying the reaction temperature and the molar ratio of $\mathrm{F}^{-} / \mathrm{Ln}^{3+}(\mathrm{Ln}=\mathrm{Lu}+\mathrm{Yb}+\mathrm{Er} / \mathrm{Ho} / \mathrm{Tm})$ precursor. Figure 1 shows X-ray diffraction (XRD) patterns of $\mathrm{NaLuF}_{4}: \mathrm{Yb}^{3+} / \mathrm{Er}^{3+}\left(\mathrm{Tm}^{3+}, \mathrm{Ho}^{3+}\right) \mathrm{NCs}$ hydrothermally prepared at various temperatures with the molar ratio of $\mathrm{F}^{-} / \mathrm{Ln}^{3+}(\mathrm{Ln}=\mathrm{Lu}+\mathrm{Yb}+\mathrm{Er} / \mathrm{Ho} / \mathrm{Tm})$ fixed at 4:1. Figure 1 reveals that the phase transition process $\left(\beta \rightarrow \alpha\right.$ or $\alpha \rightarrow \beta$ ) occurs at a reaction temperature of $T=100$ or $120^{\circ} \mathrm{C}$. The sample obtained at low temperature $\left(T=100\right.$ or $\left.120^{\circ} \mathrm{C}\right)$ shows nearly pure $\alpha$-phase (JCPDS No. 27-0725). The diffraction peaks of $\beta-\mathrm{NaLuF}_{4}$ appear at temperatures between 140 and $160{ }^{\circ} \mathrm{C}($ See Figure $1 \mathrm{c}, \mathrm{d})$, while at $180{ }^{\circ} \mathrm{C}$, only pure $\beta$-phase $\mathrm{NaLuF}_{4}$ exists. It could be concluded that low temperature favors the formation of pure $\alpha-\mathrm{NaLuF}_{4}$ core NCs. 


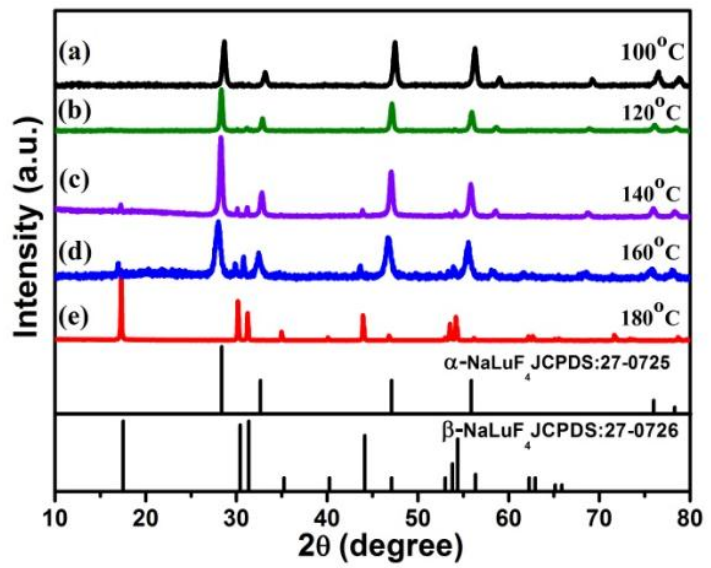

Figure 1. The X-ray diffraction patterns of $\mathrm{NaLuF}_{4}: \mathrm{Yb}^{3+} / \mathrm{Ln}^{3+}$ nanocrystals synthesized at different hydrothermal temperature: (a) $100{ }^{\circ} \mathrm{C}$; (b) $120^{\circ} \mathrm{C}$; (c) $140{ }^{\circ} \mathrm{C}$; (d) $160^{\circ} \mathrm{C}$; (e) $180{ }^{\circ} \mathrm{C}$. All samples were prepared at $\mathrm{F}^{-} / \mathrm{Ln}^{3+}=4: 1$.

Next, we investigated the role of the molar ratio of $\mathrm{F}^{-} / \mathrm{Ln}^{3+}(\mathrm{Ln}=\mathrm{Lu}+\mathrm{Yb}+\mathrm{Er} / \mathrm{Ho} / \mathrm{Tm})$ precursor on the crystal phase of our product when setting the synthesis temperature at $140{ }^{\circ} \mathrm{C}$. As can be seen in Figure 2, when the molar ratio of $\mathrm{F}^{-} / \mathrm{Ln}^{3+}$ is fixed at 4:1, the sample shows a mixture of $\alpha$-phase (JCPDS No. 27-0725) and $\beta$-phase (JCPDS No. 27-0726). As the $\mathrm{F}^{-} / \mathrm{Ln}^{3+}$ ratio is reduced to 3.5:1, the intensities of peaks of $\beta-\mathrm{NaLuF}_{4}$ decreases (Figure $2 b$ ). A pure $\alpha$-phase $\mathrm{NaLuF}_{4} \mathrm{NCs}$ can be produced at the ratio of $\mathrm{F}^{-} / \mathrm{Re}^{3+}$ below $3: 1$, and the diffraction peaks of $\alpha-\mathrm{NaLuF}_{4}$ sample at $\mathrm{F}^{-} / \mathrm{Re}^{3+}=3: 1$ show stronger intensity than at $\mathrm{F}^{-} / \mathrm{Re}^{3+}=2.5: 1$ and 2:1. The average crystallite size of the nanocrystals was calculated according to Scherrer's equation [51],

$$
D=K \lambda / \beta \cos \theta
$$

where $K=0.89$, D represents the crystallite size (in nanometers), $\lambda$ is the wavelength of the $\mathrm{CuK} \alpha$ radiation, $\beta$ is the corrected half-width of the diffraction peak, and $\theta$ is Bragg's angle of the diffraction peak. According to Equation (1) and the half width of the main diffraction peak at $28^{\circ}$ in Figure 2, the average size was calculated to be about $10 \mathrm{~nm}$ for $\mathrm{F}^{-} / \mathrm{Re}^{3+}=3: 1$, in good agreement with the TEM result (Figure 3b). As a consequence, we selected $\alpha-\mathrm{NaLuF}_{4}$ nanoparticles prepared at $\mathrm{F}^{-} / \mathrm{Re}^{3+}=3: 1$ and $T=140{ }^{\circ} \mathrm{C}$ to epitaxially grow the $\alpha-\mathrm{NaLuF}_{4}: \mathrm{Yb} / \mathrm{Ln} @ \mathrm{CaF}_{2}$ core/shell structure.

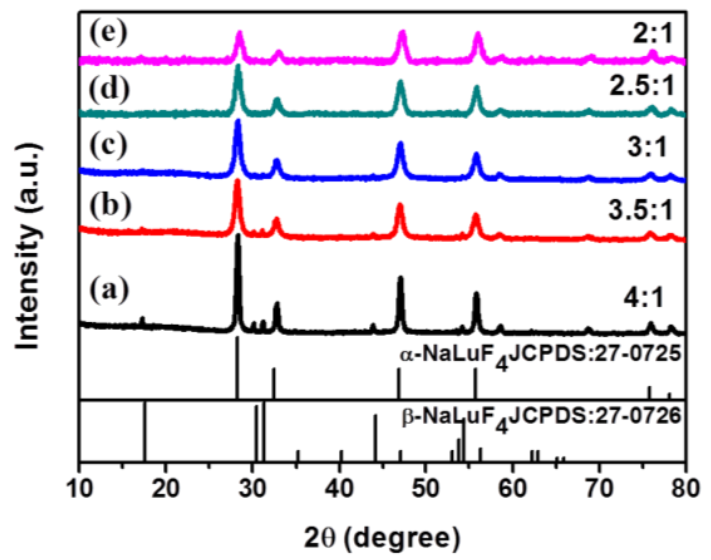

Figure 2. The X-ray diffraction patterns of $\mathrm{NaLuF}_{4}: \mathrm{Yb}^{3+} / \mathrm{Er}^{3+}$ nanocrystals synthesized with molar ratio of $\mathrm{F}^{-} / \operatorname{Re}^{3+}=$ (a) $4: 1$; (b) 3.5:1; (c) 3:1; (d) 2.5:1; (e) 2:1. ( $\mathrm{T}=140{ }^{\circ} \mathrm{C}$ ). 


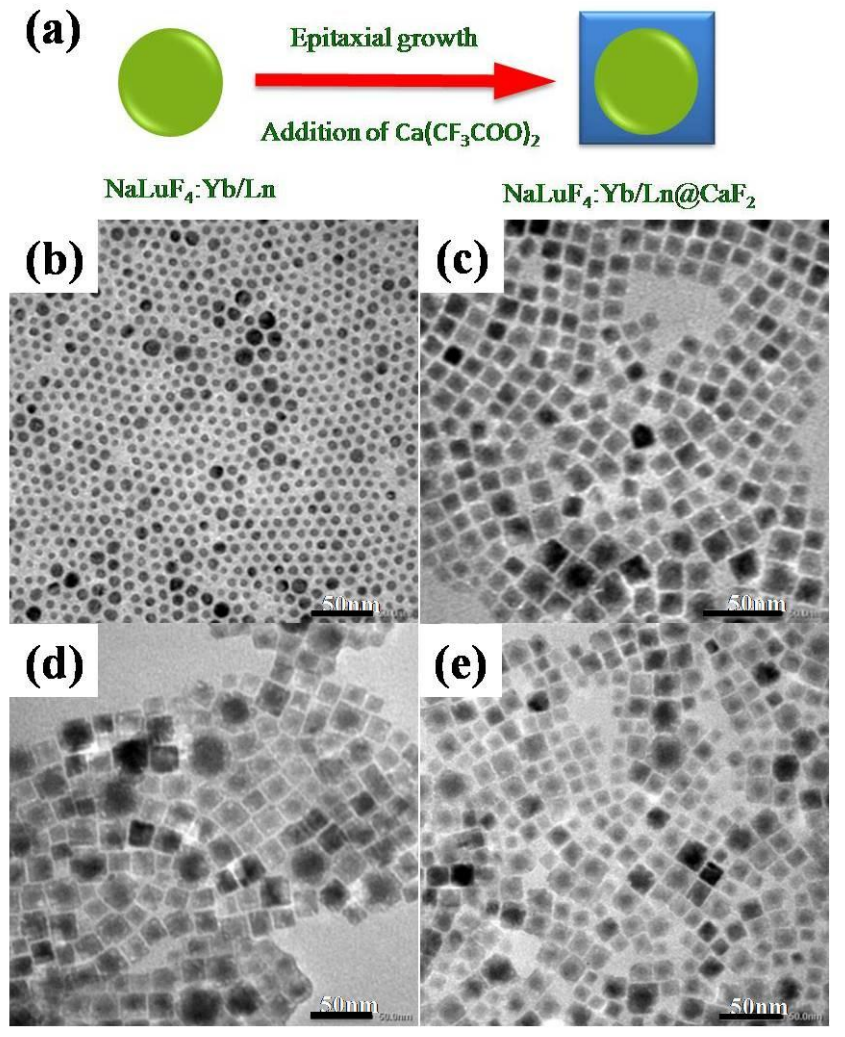

Figure 3. (a) Schematic illustration of the epitaxial growth of $\mathrm{CaF}_{2}$ shell on $\alpha-\mathrm{NaLuF}_{4}: \mathrm{Yb}^{3+} / \mathrm{Ln}^{3+}$ core nanoparticles (NPs); (b) TEM image of $\alpha-\mathrm{NaLuF}_{4}: \mathrm{Yb}^{3+} / \mathrm{Ln}^{3+}$ core nanocrystals prepared at $\mathrm{F}^{-} / \mathrm{Re}^{3+}=3: 1$ and $\mathrm{T}=140{ }^{\circ} \mathrm{C}$. TEM images of (c) $\mathrm{NaLuF}_{4}: \mathrm{Yb}^{3+} / \mathrm{Er}^{3+} @ \mathrm{CaF}_{2}$ core/shell upconversion nanocrystals (UCNCs); (d) $\alpha-\mathrm{NaLuF}_{4}: \mathrm{Yb}^{3+} / \mathrm{Ho}^{3+} @ \mathrm{CaF}_{2}$ core/shell UCNCs; (e) $\alpha-\mathrm{NaLuF}_{4}: \mathrm{Yb}^{3+} / \mathrm{Ln}^{3+} @ \mathrm{CaF}_{2}$ core/shell UCNCs. Particles in (c-e) were synthesized by the thermal decomposition method.

The principle for the epitaxial growth of the core/shell structure is illustrated in Figure 3a, which involves an injection of the $\left(\mathrm{CF}_{3} \mathrm{COO}\right)_{2} \mathrm{Ca}$ solution into the growing solution containing pre-synthesized $\alpha-\mathrm{NaLuF}_{4}: \mathrm{Yb} / \mathrm{Ln}$ core nanocrystals prepared at $\mathrm{F}^{-} / \mathrm{Re}^{3+}=3: 1$ and $T=140{ }^{\circ} \mathrm{C}$. The morphologies and sizes of the $\alpha-\mathrm{NaLuF}_{4}: \mathrm{Yb}^{3+} / \mathrm{Ln}^{3+}$ core and the resulting $\alpha-\mathrm{NaLuF}_{4}: \mathrm{Yb}^{3+} / \mathrm{Ln}^{3+} @ \mathrm{CaF}_{2}$ core/shell nanoparticles were examined by transmission electron microscopy (TEM), and the results are shown in Figure 3b. As one can see, the $\alpha-\mathrm{NaLuF}_{4}: \mathrm{Yb}^{3+} / \mathrm{Ln}^{3+}$ core has sphere-like morphology with a size of $9 \pm 0.9 \mathrm{~nm}$, in good agreement with the XRD result in Figure 2c.

After growing the $\mathrm{CaF}_{2}$ shell, the core/shell NCs showed a cubic morphology with a size of $15.6 \pm 1.2 \mathrm{~nm}$ (Figure 3c-e). The size difference indicated that a $\mathrm{CaF}_{2}$ shell with a thickness of about $3.3 \pm 0.3 \mathrm{~nm}$ was grown on the surface of $\alpha-\mathrm{NaLuF}_{4}: \mathrm{Yb}^{3+} / \mathrm{Ln}^{3+}$ core. Moreover, the formation of core/shell structure can be seen in the TEM images, shown in Figure 3c-e.

The XRD peaks of the $\alpha-\mathrm{NaLuF}_{4}: \mathrm{Yb}^{3+} / \mathrm{Ln}^{3+}$ core, the $\alpha-\mathrm{NaLuF}_{4}: \mathrm{Yb}^{3+} / \mathrm{Er}^{3+} @ \mathrm{CaF}_{2}$ core/shell, the $\mathrm{NaLuF}_{4}: \mathrm{Yb}^{3+} / \mathrm{Ho}^{3+} @ \mathrm{CaF}_{2}$ core/shell, and the $\mathrm{NaLuF}_{4}: \mathrm{Yb}^{3+} / \mathrm{Tm}^{3+} @ \mathrm{CaF}_{2}$ core/shell UCNCs are presented in Figure 4. As one can see, the core and core/shell NCs have identical peak positions, agreeing well with the standard JCPDF27-0725 sample of cubic $\mathrm{NaLuF}_{4}$ and JCPDF 02-1302 sample of cubic $\mathrm{CaF}_{2}$. The well-defined peaks are indicative of the high crystallinity of both the core and the core/shell NCs. The narrower XRD peaks of the core/shell NCs compared to that of core NPs indicate the larger size of core/shell NCs, in accordance with the TEM results in Figure 3. 


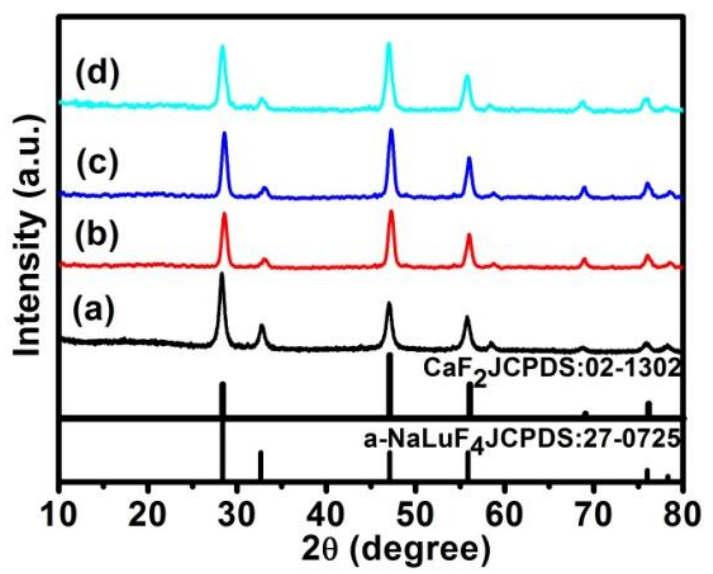

Figure 4. The X-ray diffraction patterns of the (a) $\alpha-\mathrm{NaLuF}_{4}: \mathrm{Yb}^{3+} / \mathrm{Ln}^{3+} \mathrm{NCs}$; (b) $\alpha-\mathrm{NaLuF}_{4}: \mathrm{Yb}^{3+} /$ $\mathrm{Er}^{3+} @ \mathrm{CaF}_{2}$ core/shell UCNCs; (c) $\alpha-\mathrm{NaLuF}_{4}: \mathrm{Yb}^{3+} / \mathrm{Ho}^{3+} @ \mathrm{CaF}_{2}$ core/shell UCNCs; and (d) the $\alpha-\mathrm{NaLuF}_{4}: \mathrm{Yb}^{3+} / \mathrm{Tm}^{3+} @ \mathrm{CaF}_{2}$ core/shell UCNCs, in reference to the standard diffraction patterns of the $\alpha$-phase $\mathrm{NaLuF}_{4}$ (JCPDS 27-0725) and cubic phase CaF 2 (JCPDS 02-1302).

\subsection{Characterization of $\alpha-\mathrm{NaLuF}_{4}: \mathrm{Yb}^{3+} / \mathrm{Ln}^{3+} @ \mathrm{CaF}_{2}(\mathrm{Ln}=\mathrm{Er}$, Tm, or Ho) Core/Shell UCNCs}

We compared the UCPL from the corresponding core $\mathrm{NaLuF}_{4}: 20 \% \mathrm{Yb}^{3+} / 2 \% \mathrm{Ln}^{3+}$ and the core/shell $\mathrm{NaLuF}_{4}: 20 \% \mathrm{Yb}^{3+} / 2 \% \mathrm{Ln}^{3+} @ \mathrm{CaF}_{2} \mathrm{UCNCs}(\mathrm{Ln}=\mathrm{Er}, \mathrm{Ho}$, and Tm) (Figure 5). As shown in Figure 5a, two UC bands with maxima at 525/540 nm and $660 \mathrm{~nm}$ were observed from both the $\mathrm{NaLuF}_{4}: 20 \% \mathrm{Yb}^{3+} / 2 \% \mathrm{Er}^{3+}$ core and the $\mathrm{NaLuF}_{4}: 20 \% \mathrm{Yb}^{3+} / 2 \% \mathrm{Er}^{3+} @ \mathrm{CaF}_{2}$ core/shell UCNCs, corresponding to the ${ }^{2} \mathrm{H}_{11 / 2} /{ }^{4} \mathrm{~S}_{3 / 2} \rightarrow{ }^{4} \mathrm{I}_{15 / 2}$ and the ${ }^{4} \mathrm{~F}_{9 / 2} \rightarrow{ }^{4} \mathrm{I}_{15 / 2}$ transitions of $\mathrm{Er}^{3+}$ ions, respectively. Moreover, the intensity of UCPL from core/shell UCNCs is dramatically higher than that of core nanoparticles. The intensity for UCPL band at $540 \mathrm{~nm}$ from the $\mathrm{NaLuF}_{4}: 20 \% \mathrm{Yb}^{3+} / 2 \% \mathrm{Er}^{3+} @ \mathrm{CaF}_{2}$ core/shell NCs were found to be about 656 times higher than that from the $\alpha-\mathrm{NaLuF}_{4}: \mathrm{Yb}^{3+} / \mathrm{Er}^{3+}$ core nanocrystals. Moreover, according to Figure $5 b, c$, when compared with the $\alpha-\mathrm{NaLuF}_{4}: \mathrm{Yb}^{3+} / \mathrm{Ho}^{3+}$ and $\alpha-\mathrm{NaLuF}_{4}: \mathrm{Yb}^{3+} / \mathrm{Tm}^{3+}$ core nanocrystals, the intensity of UCPL from the corresponding core/shell UCNCs showed a 772- and 75-fold enhancement, respectively. Taken together, we conclude that the core/shell structure resulted in a significant UCPL enhancement of the core nanocrystals. Since the $\mathrm{CaF}_{2}$ is an inactive layer, such an impressive enhancement undoubtedly arises from the suppression of surface quenching effects on the surface of core nanoparticles. In fact, the ultrasmall size $(9 \mathrm{~nm})$ of the core UCNCs is able to expose most of the doped sensitizer $\left(\mathrm{Yb}^{3+}\right)$ and the doped activator $\left(\mathrm{Er}^{3+} / \mathrm{Ho}^{3+} / \mathrm{Tm}^{3+}\right)$ to surface quenching effects (surface defects, surface strains, ligand and solvent molecules with groups possessing high vibration energy) [42] due to the extremely high "surface-to-volume" ratio. The epitaxial growth of the thin $\mathrm{CaF}_{2}$ shell not only eliminates the quenching defects on the surface of the core, but also shields all the sensitizer and activator ions in the core from the environmental quenching factors. 

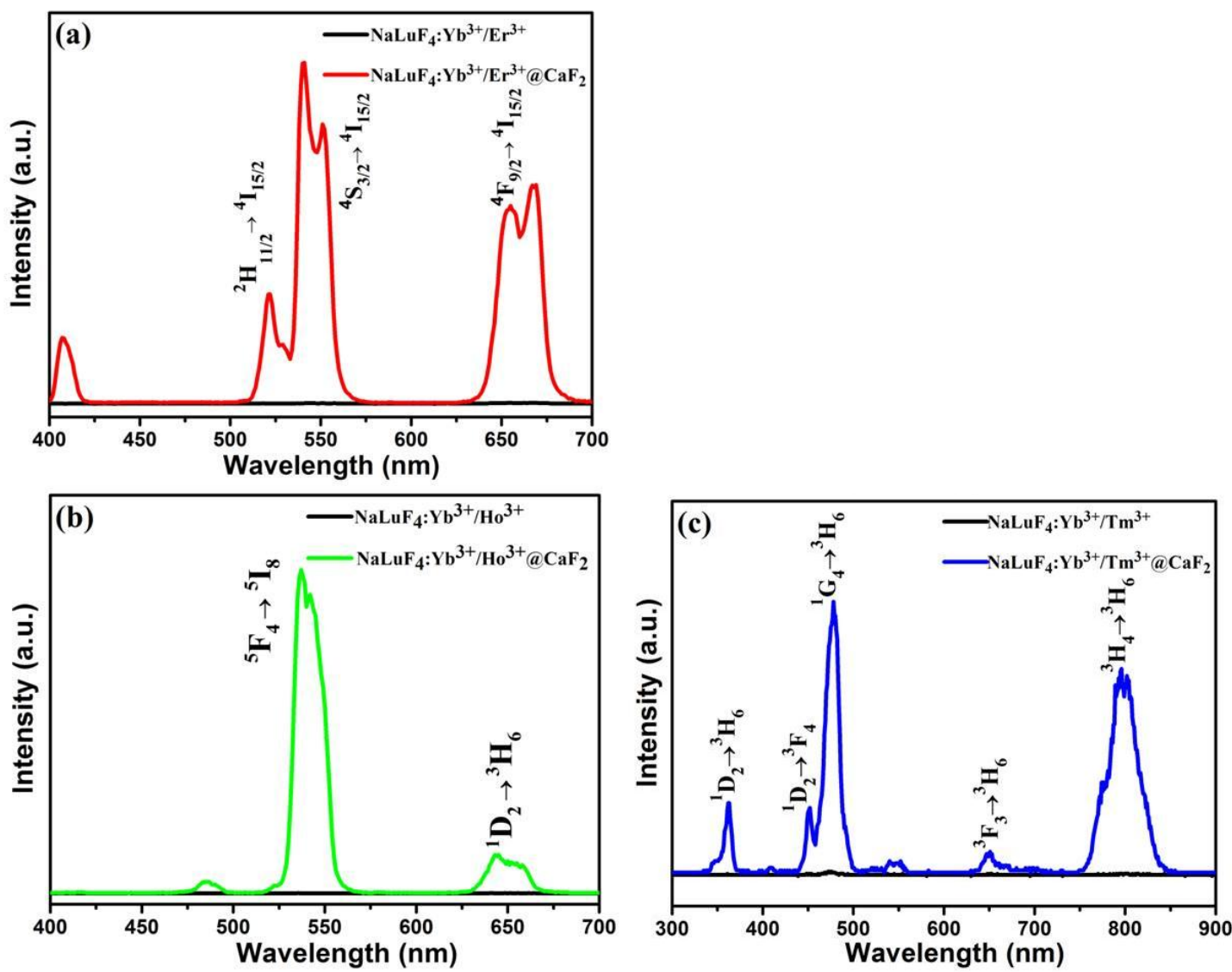

Figure 5. The upconversion luminescence spectra under excitation at $976 \mathrm{~nm}$ using a fiber-coupled laser diode: (a) the $\alpha-\mathrm{NaLuF}_{4}: \mathrm{Yb}^{3+} / \mathrm{Er}^{3+}$ core and $\alpha-\mathrm{NaLuF}_{4}: \mathrm{Yb}^{3+} / \mathrm{Er}^{3+} @ \mathrm{CaF}_{2}$ core/shell NPs; (b) the $\alpha-\mathrm{NaLuF}_{4}: \mathrm{Yb}^{3+} / \mathrm{Ho}^{3+}$ core and $\alpha-\mathrm{NaLuF}_{4}: \mathrm{Yb}^{3+} / \mathrm{Ho}^{3+} @ \mathrm{CaF}_{2}$ core/shell NPs; (c) the $\alpha-\mathrm{NaLuF}_{4}: \mathrm{Yb}^{3+} /$ $\mathrm{Tm}^{3+}$ core and $\alpha-\mathrm{NaLuF}_{4}: \mathrm{Yb}^{3+} / \mathrm{Tm}^{3+} @ \mathrm{CaF}_{2}$ core/shell NPs. The concentration of $\mathrm{Ln}^{3+}$ in all samples was kept identical at about $0.5 \mathrm{mmol}$ nanoparticles (i.e., nanoparticles formed by $0.5 \mathrm{mmol}$ lanthanide precursors) per $10 \mathrm{~mL}$ cyclohexane.

To illustrate the UC mechanisms of the $\mathrm{NaLuF}_{4}: 20 \% \mathrm{Yb}^{3+} / 2 \% \mathrm{Ln}^{3+} @ \mathrm{CaF}_{2}\left(\mathrm{Ln}^{3+}=\mathrm{Er}^{3+}, \mathrm{Ho}^{3+}, \mathrm{Tm}^{3+}\right)$ $\mathrm{NCs}$, possible UC processes are schematically given in the energy level diagrams of $\mathrm{Yb}^{3+}, \mathrm{Er}^{3+}, \mathrm{Ho}^{3+}$, and $\mathrm{Tm}^{3+}$ ions in Figure 6. The observed green UC bands $\left({ }^{2} \mathrm{H}_{11 / 2} \rightarrow{ }^{4} \mathrm{I}_{15 / 2}, 525 \mathrm{~nm} ;{ }^{4} \mathrm{~S}_{3 / 2} \rightarrow{ }^{4} \mathrm{I}_{15 / 2}\right.$, $540 \mathrm{~nm})$ and red UC band $\left({ }^{4} \mathrm{~F}_{9 / 2} \rightarrow{ }^{4} \mathrm{I}_{15 / 2}, 660 \mathrm{~nm}\right)$ from $\mathrm{Er}^{3+}$ ions in $\mathrm{NaLuF}_{4}: 20 \% \mathrm{Yb}^{3+} / 2 \% \mathrm{Er}^{3+} @ \mathrm{CaF}_{2}$ UCNCs may take place via the following process: $\mathrm{Yb}^{3+}$ ion absorbs one laser photon and gets excited from the ground ${ }^{2} \mathrm{~F}_{7 / 2}$ state to the exclusive excited ${ }^{2} \mathrm{~F}_{5 / 2}$ state. The $\mathrm{Yb}^{3+}$ ions in the excited state transfer their absorbed energy to neighboring $\mathrm{Er}^{3+}$ ions and excite them from the ground ${ }^{4} \mathrm{I}_{15 / 2}$ state to the ${ }^{4} \mathrm{I}_{11 / 2}$ state, then to the ${ }^{4} \mathrm{~F}_{7 / 2}$ state. Multiphonon assisted relaxations from the ${ }^{4} \mathrm{~F}_{7 / 2}$ state can decay nonradiatively to the lower ${ }^{2} \mathrm{H}_{11 / 2}$ and ${ }^{4} \mathrm{~S}_{3 / 2}$ levels, emitting the 525 and $540 \mathrm{~nm} \mathrm{UCL}$, respectively. The red emission $660 \mathrm{~nm}$ originates from the ${ }^{4} \mathrm{~F}_{9 / 2} \rightarrow{ }^{4} \mathrm{I}_{15 / 2}$ transition, and the ${ }^{4} \mathrm{~F}_{9 / 2}$ state can be populated either from nonradiative relaxations from the ${ }^{4} S_{3 / 2}$ level or the energy transfer from $\mathrm{Yb}^{3+}$ ions to the $\mathrm{Er}^{3+}$ ion at the ${ }^{4} \mathrm{I}_{13 / 2}$ state. In addition, the processes for green $\left({ }^{5} \mathrm{~F}_{4} \rightarrow{ }^{5} \mathrm{I}_{8}, 537 \mathrm{~nm}\right)$ and red $\left({ }^{5} \mathrm{~F}_{5} \rightarrow{ }^{5} \mathrm{I}_{8}, 645 \mathrm{~nm}\right) \mathrm{UCL}$ of $\mathrm{Ho}^{3+}$ ions involved two different centers-the sensitizer $\left(\mathrm{Yb}^{3+}\right)$, the activator $\left(\mathrm{Ho}^{3+}\right)$-along with two successive transfers from $\mathrm{Yb}^{3+}$ ions to $\mathrm{Ho}^{3+}$ ions. In the first transfer, the $\mathrm{Yb}^{3+}$ ion absorbs the excitation photons through the ground state absorption and transfers its absorbed energy to the neighboring $\mathrm{Ho}^{3+}$ ion to populate to its intermediate $\left({ }^{5} \mathrm{I}_{6}\right.$ level). The energy difference between the two levels was abridged by the vibration energy of the host lattice. The second transfer is to promote the population from the intermediate ${ }^{5} \mathrm{I}_{6}$ level to the emitting energy levels $\left({ }^{5} \mathrm{~S}_{2}\right)$ by energy transfer (ET) from another excited $\mathrm{Yb}^{3+}$ ion [52]. Once the ${ }^{5} \mathrm{~S}_{2}$ level is populated, the 
excited electron can release its energy by emitting green emissions. The red emission at $645 \mathrm{~nm}$ can be produced by radiative decay to the ground ${ }^{5} \mathrm{~F}_{5}$ state. The blue UCL of $\mathrm{Tm}^{3+}$ occurs via a three-step ET from $\mathrm{Yb}^{3+}$ to $\mathrm{Tm}^{3+}$. First, the $\mathrm{Tm}^{3+}$ ion in the ground state ${ }^{3} \mathrm{H}_{6}$ is excited to the state ${ }^{3} \mathrm{H}_{5}$ via an ET from a neighboring excited $\mathrm{Yb}^{3+}$ ion. Subsequent nonradiative relaxation of ${ }^{3} \mathrm{H}_{5} /{ }^{3} \mathrm{~F}_{4}$ populates the ${ }^{3} \mathrm{~F}_{4}$ level. In the second-step excitation, the $\mathrm{Tm}^{3+}$ ion in the ${ }^{3} \mathrm{~F}_{4}$ state is excited to the ${ }^{3} \mathrm{~F}_{2,3}$ state via another ET from a neighboring excited $\mathrm{Yb}^{3+}$ ion. The populated ${ }^{3} \mathrm{~F}_{2}$ level may nonradiatively relax to the ${ }^{3} \mathrm{~F}_{3}$ level. When the $\mathrm{Tm}^{3+}$ ion at the ${ }^{3} \mathrm{~F}_{3}$ level decays to the ground state, a weak red emission $\left({ }^{3} \mathrm{~F}_{3} \rightarrow{ }^{3} \mathrm{H}_{6}\right)$ is produced. Additionally, the near-infrared UCL at $802 \mathrm{~nm}$ arises from the ${ }^{3} \mathrm{H}_{4} \rightarrow{ }^{3} \mathrm{H}_{6}$ transition, where the ${ }^{3} \mathrm{H}_{4}$ state is populated by the efficient nonradiative relaxation from the ${ }^{3} \mathrm{~F}_{2,3}$ state. A third energy transfer from $\mathrm{Yb}^{3+}$ excites $\mathrm{Tm}^{3+}$ at the ${ }^{3} \mathrm{~F}_{3}$ level to the ${ }^{1} \mathrm{G}_{4}$ level, from which the blue emission $\left({ }^{1} \mathrm{G}_{4} \rightarrow{ }^{3} \mathrm{H}_{6}\right)$ occurs by radiative decay to the ground state. The fourth energy transfer from $\mathrm{Yb}^{3+}$ promotes the $\mathrm{Tm}^{3+}$ at the ${ }^{1} \mathrm{G}_{4}$ level to the ${ }^{1} \mathrm{D}_{2}$ level, from which a $360 \mathrm{~nm}$ ultraviolet UCL $\left({ }^{1} \mathrm{D}_{2} \rightarrow{ }^{3} \mathrm{H}_{6}\right)$ is generated.

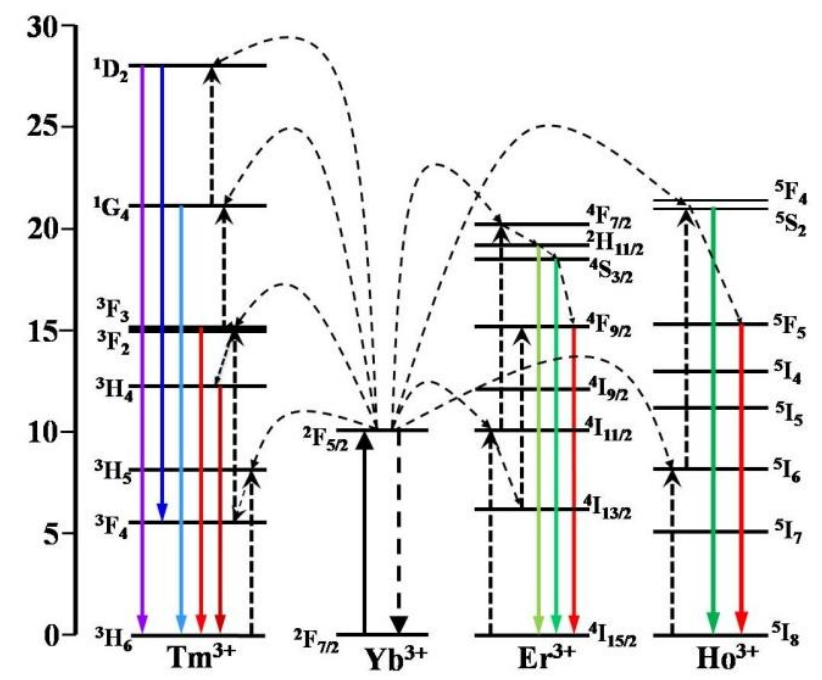

Figure 6. The energy level diagrams of $\mathrm{Yb}^{3+}, \mathrm{Er}^{3+}, \mathrm{Tm}^{3+}$, and $\mathrm{Ho}^{3+}$ ions, showing the proposed upconversion mechanisms in the $\alpha-\mathrm{NaLuF}_{4}: \mathrm{Yb}^{3+} / \mathrm{Ln}^{3+} @ \mathrm{CaF}_{2}(\mathrm{Ln}=\mathrm{Er}, \mathrm{Ho}$, or Tm) core/ shell UCNCs.

\section{Materials and Methods}

\subsection{Materials}

All $\mathrm{Ln}_{2} \mathrm{O}_{3}(99.9 \%, \mathrm{Ln}=\mathrm{Lu}, \mathrm{Yb}, \mathrm{Er}, \mathrm{Tm}, \mathrm{Ho})$ were obtained from Jianfeng Rare-Earth Limited Company, Conghua, China. The basic chemical reagents, such as sodium hydroxide, oleic acid (OA), absolute ethyl alcohol, trifluoroacetic acid (TFA), calcium oxide, sodium fluoride and octadecene (ODE) were purchased from Sinopharm Chemical Reagent Co., Ltd., Beijing, China. All chemicals were of analytical grade and were used as received without further purification.

\subsection{Hydrothermal Synthesis of $\alpha-\mathrm{NaLuF}_{4}: \mathrm{Yb}^{3+} / \mathrm{Ln}^{3+} \mathrm{UCNCS}$}

We synthesized $\alpha-\mathrm{NaLuF}_{4}: \mathrm{Yb}^{3+} / \mathrm{Ln}^{3+}(\mathrm{Ln}=\mathrm{Er}, \mathrm{Tm}$, or Ho) nanocrystals by a hydro-thermal method adapted from the literature [53]. Typically, $0.6 \mathrm{~g}$ of $\mathrm{NaOH}, 3 \mathrm{~mL}$ of water, $14 \mathrm{~mL}$ of oleic acid (OA) $(90 \mathrm{wt} . \%)$, and $10 \mathrm{~mL}(120 \mathrm{mmol})$ of ethanol were well-mixed at room temperature to yield a white viscous solution. Then, $1 \mathrm{mmol} \mathrm{Ln}\left(\mathrm{NO}_{3}\right)_{3}\left(\mathrm{Ln}=\mathrm{Lu}, \mathrm{Yb}, \mathrm{Er}, \mathrm{Tm}, \mathrm{Ho}\right.$, and $\mathrm{Lu}^{3+}: \mathrm{Yb}^{3+}: \mathrm{Er}^{3+} / \mathrm{Tm}^{3+} / \mathrm{Ho}^{3+}$ $=78 \%: 20 \%: 2 \% / 2 \% / 2 \%$ ) was added into the above solution and kept vigorous stirring. After aging for $30 \mathrm{~min}, 4 \mathrm{~mL}(4 \mathrm{mmol})$ of $\mathrm{NaF}\left(\mathrm{F}^{-} / \mathrm{Ln}^{3+}=4: 1\right)$ solution was added under vigorous stirring for $30 \mathrm{~min}$. Subsequently, the mixture was transferred to a 50-mL Teflon-lined autoclave and heated at $140-180{ }^{\circ} \mathrm{C}$ for $24 \mathrm{~h}$. After washing with ethanol, the final products were dispersed in cyclohexane. 


\subsection{Thermal Decomposition Synthesis of $\alpha-N a L u F_{4}: \mathrm{Yb}^{3+} / \mathrm{Ln}^{3+} @ \mathrm{CaF}_{2}$ Core/Shell UCNCs}

The core/shell nanoparticles were synthesized using the thermal decomposition method. Typically, $0.5 \mathrm{mmol} \mathrm{CaO}$ was first added to a $50 \mathrm{~mL}$ flask containing $5 \mathrm{~mL}$ deionized water and $5 \mathrm{~mL}$ trifluoroacetic acid (TFA). The solution was heated at $90{ }^{\circ} \mathrm{C}$ until the solution became transparent, and was then dried at this temperature with nitrogen purge to yield the shell precursor $\left(\mathrm{CF}_{3} \mathrm{COO}\right)_{2} \mathrm{Ca}$. After obtaining the $\left(\mathrm{CF}_{3} \mathrm{COO}\right)_{2} \mathrm{Ca}$ powders, $10 \mathrm{~mL}$ of $\mathrm{OA}, 10 \mathrm{~mL}$ of $\mathrm{ODE}$, and the pre-prepared $\alpha-\mathrm{NaLuF}_{4}: \mathrm{Yb}^{3+} / \mathrm{Ln}^{3+}(0.5 \mathrm{mmol})$ in cyclohexane were added. The solution was then vacuum-degassed at $120^{\circ} \mathrm{C}$ for $30 \mathrm{~min}$ to remove water, oxygen, and cyclohexane. Subsequently, the solution was heated to $300{ }^{\circ} \mathrm{C}$ at a rate of $15 \mathrm{~K} \cdot \mathrm{min}^{-1}$ under nitrogen protection. After maintaining at $300{ }^{\circ} \mathrm{C}$ for $30 \mathrm{~min}$, the reaction was stopped and cooled down to room temperature. After washing with ethanol, the products were dispersed in cyclohexane for further use.

\subsection{Thermal Decomposition Synthesis of $\alpha-\mathrm{NaLuF}_{4}: \mathrm{Yb}^{3+} / \mathrm{Ln}^{3+} @ \mathrm{CaF} 2$ Core/Shell UCNCs}

The size and morphology of the $\alpha-\mathrm{NaLuF}_{4}: \mathrm{Yb}^{3+} / \mathrm{Ln}^{3+}$ and $\alpha-\mathrm{NaLuF}_{4}: \mathrm{Yb}^{3+} / \mathrm{Ln}^{3+} @ \mathrm{CaF}_{2}$ core/shell nanocrystals were characterized by transmission electron microscopy (TEM) using a JEOL JEM-2010 microscope (JEOL Ltd., Tokyo, Japan) at an acceleration voltage of $200 \mathrm{kV}$. The powder X-ray diffraction (XRD) patterns were recorded by a Siemens D500 diffractometer (Bruker Beijing Scientific Technology Co. Ltd, Beijing, China) using $\mathrm{Cu} \mathrm{K} \alpha$ radiation $(\lambda=0.15418 \mathrm{~nm})$. The $2 \theta$ angle of the XRD spectra was recorded at a scanning rate of $5^{\circ} / \mathrm{min}$. The UCPL spectra were obtained using a Zolix monochoromator (Beijing Zolix Instruments CO., Ltd., Beijing, China) under excitation at $976 \mathrm{~nm}$ using a fiber-coupled laser diode (BWT Beijing Ltd., Beijing, China).

\section{Conclusions}

In summary, cubic phase $\alpha-\mathrm{NaLuF}_{4}: \mathrm{Yb} / \mathrm{Ln}$ cores can be precisely controlled through a simple variation of reaction temperature and the added amount of $\mathrm{NaF}$ in a hydrothermal method. Moreover, a seed-mediated growth protocol with selected parameters favorable for shell growth yields the $\alpha-\mathrm{NaLuF}_{4}: \mathrm{Yb} / \mathrm{Ln} @ \mathrm{CaF}_{2}(\mathrm{Ln}=\mathrm{Er}, \mathrm{Ho}, \mathrm{Tm})$ core/shell structure NPs having a core size of $\sim 9 \mathrm{~nm}$ and shell thickness of $\sim 3.3 \mathrm{~nm}$. Moreover, we found that the growth of the inert thin shell of $\mathrm{CaF}_{2}$ onto the $\alpha-\mathrm{NaLuF}_{4}: \mathrm{Yb} / \mathrm{Ln}(\mathrm{Ln}=\mathrm{Er}, \mathrm{Ho}, \mathrm{Tm})$ core could enhance its multicolor UCL by up to 772-fold, being attributed to effective suppression of surface-related quenching effects via spatial isolation of the core from the surrounding environment. Small-sized $\alpha-\mathrm{NaLuF}_{4}: \mathrm{Yb} / \mathrm{Ln} @ \mathrm{CaF}_{2}(\mathrm{Ln}=\mathrm{Er}, \mathrm{Ho}, \mathrm{Tm}) \mathrm{UCNCs}$ developed here have implication for uses in a range of biophotonic applications, such as bioimaging.

Acknowledgments: This work is supported in part by National Natural Science Foundation of China (51672061 and 51402071), National Natural Science Fund for Distinguished Young Scholars (51325201), and the Fundamental Research Funds for the Central Universities, China (AUGA5710052614, AUGA8880100415, and HIT. BRETIV.201503).

Author Contributions: Hui Li and Guanying Chen conceived and designed the experiments; Hui Li performed the experiments and drafted the manuscript; Chunhui Yang provided valuable suggestions; Guanying Chen and Shuwei Hao advised the work and edited the manuscript.

Conflicts of Interest: The authors declare no conflict of interest.

\section{References}

1. Suyver, J.F.; Aebischer, A.; Biner, D.; Gerner, P.; Grimm, J.; Heer, S.; Krämer, K.W.; Reinhard, C.; Güdel, H.U. Novel materials doped with trivalent lanthanides and transition metal ions showing near-infrared to visible photon upconversion. Opt. Mater. 2005, 27, 1111-1130. [CrossRef]

2. Suyver, J.F.; Grimm, J.; van Veen, M.K.; Biner, D.; Kramer, K.W.; Gudel, H.U. Upconversion spectroscopy and properties of $\mathrm{NaYF}_{4}$ doped with $\mathrm{Er}^{3+}, \mathrm{Tm}^{3+}$ and/or $\mathrm{Yb}^{3+}$. J. Lumin. 2006, 117, 1-12. [CrossRef]

3. Gnach, A.; Bednarkiewicz, A. Lanthanide-doped up-converting nanoparticles: Merits and challenges. Nano Today 2012, 7, 532-563. [CrossRef] 
4. Naccache, R.; Rodríguez, E.M.; Bogdan, N.; Sanz-Rodríguez, F.; de la Cruz, M.D.I.; de la Fuente, Á.J.; Vetrone, F.; Jaque, D.; Solé, J.G.; Capobianco, J.A. High resolution fluorescence imaging of cancers using lanthanide ion-doped upconverting nanocrystals. Cancers 2012, 4, 1067-1105. [CrossRef] [PubMed]

5. Tian, G.; Gu, Z.; Zhou, L.; Yin, W.; Liu, X.; Yan, L.; Jin, S.; Ren, W.L.; Xing, G.M.; Li, S.J.; et al. Mn ${ }^{2+}$ dopant-controlled synthesis of $\mathrm{NaYF}_{4}: \mathrm{Yb} /$ Er upconversion nanoparticles for in vivo imaging and drug delivery. Adv. Mater. 2012, 24, 1226-1231. [CrossRef] [PubMed]

6. Heer, S.; Koempe, K.; Guedel, H.U.; Haase, M. Highly efficient multicolor upconversion emission in transparent colloids of lanthanide-doped $\mathrm{NaYF}_{4}$ nanocrystals. Adv. Mater. 2004, 16, 2102-2105. [CrossRef]

7. Lim, S.F.; Riehn, R.; Ryu, W.S.; Khanarian, N.; Tung, C.K.; Tank, D.; Austin, R.H. In vivo and scanning electron microscopy imaging of upconverting nanophosphors in Caenorhabditis elegans. Nano Lett. 2006, 6, 169-174. [CrossRef] [PubMed]

8. Wang, F.; Liu, X. Upconversion multicolor fine-tuning: Visible to near-infrared emission from lanthanide-doped $\mathrm{NaYF}_{4}$ nanoparticles. J. Am. Chem. Soc. 2008, 130, 5642-5643. [CrossRef] [PubMed]

9. Wang, L.; Yan, R.; Huo, Z.; Wang, L.; Zeng, J.; Bao, J.; Wang, X.; Peng, Q.; Li, Y. Fluorescence resonant energy transfer biosensor based on upconversion-luminescent nanoparticles. Angew. Chem. 2005, 44, 6054-6057. [CrossRef] [PubMed]

10. Yao, L.; Jing, Z.; Liu, J.; Wei, F.; Li, F. Iridium-complex-modified upconversion nanophosphors for effective LRET detection of cyanide anions in pure water. Adv. Funct. Mater. 2012, 22, 2667-2672. [CrossRef]

11. Miyazaki, D.; Lasher, M.; Fainman, Y. Fluorescent volumetric display excited by a single infrared beam. Appl. Opt. 2005, 44, 5281-5285. [CrossRef] [PubMed]

12. Zhao, J.; Zheng, X.; Schartner, E.P.; Lonescu, P.; Zhang, R.; Nguyen, T.L.; Jin, D.; Ebendorff-Heidepriem, H. Upconversion nanocrystal-doped glass: A new paradigm for photonic materials. Adv. Opt. Mater. 2016, 4, 1507-1517. [CrossRef]

13. Deng, R.; Qin, F.; Chen, R.; Huang, W.; Hong, M.; Liu, X. Temporal full-colour tuning through non-steady-state upconversion. Nat. Nanotechnol. 2015, 10, 237-242. [CrossRef] [PubMed]

14. Wang, F.; Liu, X. Recent advances in the chemistry of lanthanide-doped upconversion nanocrystals. Chem. Soc. Rev. 2009, 38, 976-989. [CrossRef] [PubMed]

15. Ouyang, J.; Yin, D.; Cao, X.; Wang, C.; Song, K.; Liu, B.; Zhang, L.; Han, Y.; Wu, W. Synthesis of NaLuF 4 -based nanocrystals and large enhancement of upconversion luminescence of $\mathrm{NaLuF}_{4}: \mathrm{Gd}, \mathrm{Yb}$, Er by coating an active shell for bioimaging. Dalton Trans. 2014, 43, 14001-14008. [CrossRef] [PubMed]

16. Dong, C.; Korinek, A.; Blasiak, A.B.; Tomanek, B.; van Veggel, F.C.J.M. Cation Exchange: A Facile Method to Make $\mathrm{NaYF}_{4}: \mathrm{Yb}, \mathrm{Tm}-\mathrm{NaGdF}_{4}$ Core-Shell Nanoparticles with a Thin, Tunable, and Uniform Shell. Chem. Mater. 2012, 24, 1297-1305. [CrossRef]

17. Liu, Q.; Sun, Y.; Yang, T.; Feng, W.; Li, C.; Li, F. Sub-10 nm hexagonal lanthanide-doped NaLuF 4 upconversion nanocrystals for sensitive bioimaging in vivo. J. Am. Chem. Soc. 2011, 133, 17122-17125. [CrossRef] [PubMed]

18. Hu, S.; Wu, X.; Chen, Z.; Hu, P.; Yan, H.; Tang, Z.; Xi, Z.; Liu, Y. Uniform $\mathrm{NaLuF}_{4}$ nanoparticles with strong upconversion luminescence for background-free imaging of plant cells and ultralow power detecting of trace organic dyes. Mater. Res. Bull. 2016, 73, 6-13. [CrossRef]

19. Yang, T.; Sun, Y.; Liu, Q.; Feng, W.; Yang, P.; Li, F. Cubic sub-20 nm NaLuF 4 -based upconversion nanophosphors for high-contrast bioimaging in different animal species. Biomaterials 2012, 33, 3733-3742. [CrossRef] [PubMed]

20. Chen, Z.; Wu, X.; Hu, S.; Hu, P.; Yan, H.; Tang, Z.; Liu, Y. Multicolor upconversion $\mathrm{NaLuF}_{4}$ fluorescent nanoprobe for plant cell imaging and detection of sodium fluorescein. J. Mater. Chem. C 2015, 3, 153-161. [CrossRef]

21. Gao, W.; Dong, J.; Liu, J.H.; Yan, X.W. Enhancement of red upconversion emission of cubic phase $\mathrm{NaLuF}_{4}: \mathrm{Yb}^{3+} / \mathrm{Ho}^{3+} / \mathrm{Ce}^{3+}$ nanocrystals. Mater. Res. Bull. 2016, 80, 256-262. [CrossRef]

22. Liu, Q.; Feng, W.; Yang, T.S.; Yi, T.; Li, F.Y. Upconversion luminescence imaging of cells and small animals. Nat. Protoc. 2013, 114, 2033-2044. [CrossRef] [PubMed]

23. Yang, D.; Dai, Y.; Ma, P.; Kang, X.; Cheng, Z.; Li, C.; Lin, J. One-step synthesis of small-sized and water-soluble $\mathrm{NaREF}_{4}$ upconversion nanoparticles for in vitro cell imaging and drug delivery. Chem. Eur. J. 2013, 19, 2685-2694. [CrossRef] [PubMed]

24. Zhang, Y.; Huang, L.; Liu, X. Unraveling epitaxial habits in the $\mathrm{NaLnF}_{4}$ system for color multiplexing at the single-particle level. Angew. Chem. Int. Ed. 2016, 55, 5718-5722. [CrossRef] [PubMed] 
25. Shi, F.; Wang, J.; Zhai, X.; Zhao, D.; Qin, W. Facile synthesis of $\beta-\mathrm{NaLuF}_{4}$ :Yb/Tm hexagonal nanoplates with intense ultraviolet upconversion luminescence. CrystEngComm 2011, 13, 3782-3787. [CrossRef]

26. Wang, L.; Lan, M.; Liu, Z.; Qin, G.; Wu, C.; Wang, X.; Qin, W.; Huang, W.; Huang, L. Enhanced deep-ultraviolet upconversion emission of $\mathrm{Gd}^{3+}$ sensitized by $\mathrm{Yb}^{3+}$ and $\mathrm{Ho}^{3+}$ in $\beta-\mathrm{NaLuF}_{4}$ microcrystals under $980 \mathrm{~nm}$ excitation. J. Mater. Chem. C 2013, 1, 2485-2490. [CrossRef]

27. Zheng, K.Z.; Liu, Z.Y.; Lv, C.J.; Qin, W.P. Temperature sensor based on the UV upconversion luminescence of $\mathrm{Gd}^{3+}$ in $\mathrm{Yb}^{3+}-\mathrm{Tm}^{3+}-\mathrm{Gd}^{3+}$ codoped $\mathrm{NaLuF}_{4}$ microcrystals. J. Mater. Chem. C 2013, 1, 5502-5507. [CrossRef]

28. Wang, Z.; Zhang, P.; Yuan, Q.; Xu, X.; Lei, P.; Liu, X.; Su, Y.; Dong, L.; Feng, J.; Zhang, H. Nd ${ }^{3+}$-sensitized $\mathrm{NaLuF}_{4}$ luminescent nanoparticles for multimodal imaging and temperature sensing under $808 \mathrm{~nm}$ excitation. Nanoscale 2015, 7, 17861-17870. [CrossRef] [PubMed]

29. Cui, Y.; Zhao, S.L.; Liang, Z.Q.; Han, M.; Xu, Z. Optimized upconversion emission of $\mathrm{NaLuF}_{4}: \mathrm{Er}, \mathrm{Yb}$ nanocrystals codoped with $\mathrm{Gd}^{3+}$ ions and its mechanism. J. Alloy. Compd. 2014, 593, 30-33. [CrossRef]

30. Zhu, W.; Zhao, S.L.; Liang, Z.Q.; Yang, Y.X.; Zhang, J.J.; Xu, Z. The color tuning and mechanism of upconversion emission from green to red in $\mathrm{NaLuF}_{4}: \mathrm{Yb}^{3+} / \mathrm{Ho}^{3+}$ nanocrystals by codoping with $\mathrm{Ce}^{3+}$. J. Alloy. Compd. 2016, 659, 146-151. [CrossRef]

31. Zheng, K.Z.; He, G.H.; Song, W.Y.; Bi, X.Q.; Qin, W.P. A strategy for enhancing the sensitivity of optical thermometers in $\beta-\mathrm{NaLuF}_{4}: \mathrm{Yb}^{3+} / \mathrm{Er}^{3+}$ nanocrystals. J. Mater. Chem. C 2015, 3, 11589-11594. [CrossRef]

32. Lin, H.; Xu, D.K.; Teng, D.D.; Yang, S.H.; Zhang, Y.L. Shape-controllable synthesis and enhanced upconversion luminescence of $\mathrm{Li}^{+}$doped $\beta-\mathrm{NaLuF}_{4}: \mathrm{Yb}^{3+}, \mathrm{Ln}^{3+}(\mathrm{Ln}=\mathrm{Tm}, \mathrm{Ho})$ microcrystals. New J. Chem. 2015, 39, 2565-2572. [CrossRef]

33. Lin, H.; Xu, D.K.; Li, A.M.; Teng, D.D.; Yang, S.H.; Zhang, Y.L. Tuning of structure and enhancement of upconversion luminescence in $\mathrm{NaLuF}_{4}: \mathrm{Yb}^{3+}, \mathrm{Ho}^{3+}$ crystals. Phys. Chem. Chem. Phys. 2015, 17, 19515-19526. [CrossRef] [PubMed]

34. Li, C.X.; Quan, Z.W.; Yang, P.P.; Huang, S.S.; Lian, H.Z.; Lin, J. Shape-controllable synthesis and upconversion properties of lutetium fluoride (doped with $\mathrm{Yb}^{3+} / \mathrm{Er}^{3+}$ ) microcrystals by hydrothermal process. J. Phys. Chem. C 2008, 112, 13395-13404. [CrossRef]

35. Lin, H.; Xu, D.K.; Li, A.M.; Teng, D.D.; Yang, S.H.; Zhang, Y.L. Morphology evolution and pure red upconversion mechanism of $\beta-\mathrm{NaLuF}_{4}$ crystals. Sci. Rep. 2016, 6, 28051. [CrossRef] [PubMed]

36. Zeng, S.J.; Wang, H.B.; Lu, W.; Yi, Z.G.; Rao, L.; Liu, H.R.; Hao, J.H. Dual-modal upconversion fluorescent/X-ray imaging using ligand-free hexagonal phase $\mathrm{NaLuF}_{4}: \mathrm{Gd} / \mathrm{Yb} / \mathrm{Er}$ nanorods for blood vessel visualization. Biomaterials 2014, 35, 2934-2941. [CrossRef] [PubMed]

37. Liu, J.; Chen, G.Y.; Hao, S.W.; Yang, C.H. Sub-6 nm hexagonal core/shell NaGdF 4 nanocrystals with enhanced upconversion photoluminescence. Nanoscale 2017, 9, 91-98. [CrossRef] [PubMed]

38. Zhou, N.; Qiu, P.; Wang, K.; Fu, H.; Gao, G.; He, R.; Cui, D. Shape-controllable synthesis of hydrophilic $\mathrm{NaLuF}_{4}: \mathrm{Yb}$,Er nanocrystals by a surfactant-assistant two-phase system. Nanoscale Res. Lett. 2013, 8, 518. [CrossRef] [PubMed]

39. Hu, S.G.; Cao, H.Y.; Wu, X.F.; Zhan, S.P.; Wu, Q.Y.; Tang, Z.J.; Liu, Y.X. Upconversion luminescence and magnetic turning of $\mathrm{NaLuF}_{4}: \mathrm{Yb}^{3+} / \mathrm{Tm}^{3+} / \mathrm{Gd}^{3+}$ nanoparticles and their application for detecting acriflavine. J. Nanomater. 2016, 2016, 63479. [CrossRef]

40. Gargas, D.J.; Chan, E.M.; Ostrowski, A.D.; Aloni, S.; Altoe, M.V.; Barnard, E.S.; Sanii, B.; Urban, J.J.; Milliron, D.J.; Cohen, B.E.; et al. Engineering bright sub-10-nm upconverting nanocrystals for single-molecule imaging. Nat. Nanotechnol. 2014, 9, 300-305. [CrossRef] [PubMed]

41. Choi, H.S.; Liu, W.; Misra, P.; Tanaka, E.; Zimmer, J.P.; Itty, I.B.; Bawendi, M.G.; Frangioni, J.V. Renal clearance of quantum dots. Nat. Biotechnol. 2007, 25, 1165-1170. [CrossRef] [PubMed]

42. Zhao, J.B.; Lu, Z.D.; Yin, Y.D.; McRae, C.; Piper, J.A.; Dawes, J.M.; Jin, D.Y.; Goldys, E.M. Upconversion luminescence with tunable lifetime in $\mathrm{NaYF}_{4}: \mathrm{Yb}$, Er nanocrystals: Role of nanocrystal size. Nanoscale 2013, 5, 944-952. [CrossRef] [PubMed]

43. Su, Y.; Liu, X.L.; Lei, P.P.; Xu, X.; Dong, L.L.; Guo, L.M.; Yan, X.X.; Wang, P.; Song, S.Y.; Feng, J.; et al.

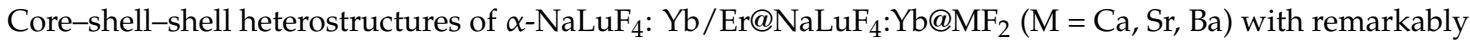
enhanced upconversion luminescence. Dalton Trans. 2016, 45, 11129-11136. [CrossRef] [PubMed]

44. Grobner, T. Gadolinium-A specific trigger for the development of nephrogenic fibrosing dermopathy and nephrogenic systemic fibrosis? Nephrol. Dial. Transplant. 2006, 21, 1104-1108. [CrossRef] [PubMed] 
45. Amuluru, L.; High, W.; Hiatt, K.M.; Ranville, J.; Shar, S.V.; Malik, B.; Swaminathan, S. Metal Deposition in Calcific Uremic Arteriolopathy. J. Am. Acad. Dermatol. 2009, 61, 73-79. [CrossRef] [PubMed]

46. Chen, G.Y.; Shen, J.; Ohulchanskyy, T.Y.; Patel, N.J.; Kutikov, A.; Li, Z.; Song, J.; Pandey, R.K.; Ågren, H.; Prasad, P.N.; et al. $\left(\alpha-\mathrm{NaYbF}_{4}: \mathrm{Tm}^{3+}\right) / \mathrm{CaF}_{2}$ Core/Shell Nanoparticles with Efficient Near-Infrared to Near-Infrared Upconversion for High-Contrast Deep Tissue Bioimaging. ACS Nano 2012, 6, 8280-8287. [CrossRef] [PubMed]

47. Hao, S.W.; Yang, L.M.; Qiu, H.L.; Fan, R.W.; Yang, C.H.; Chen, G.Y. Heterogeneous core/shell fluoride nanocrystals with enhanced upconversion photoluminescence for in vivo bioimaging. Nanoscale 2015, 7, 10775-10780. [CrossRef] [PubMed]

48. Shen, J.; Chen, G.; Ohulchanskyy, T.Y.; Kesseli, S.J.; Buchholz, S.; Li, Z.; Prasad, P.N.; Han, G. Upconversion: Tunable Near Infrared to Ultraviolet Upconversion Luminescence Enhancement in $\left(\alpha-\mathrm{NaYF}_{4}: \mathrm{Yb}, \mathrm{Tm}\right) / \mathrm{CaF}_{2}$ Core/Shell Nanoparticles for In situ Real-time Recorded Biocompatible Photoactivation. Small 2013, 9, 3213. [CrossRef] [PubMed]

49. Prorok, K.; Bednarkiewice, A.; Cichy, B.; Gnach, A.; Misiak, M.; Sobczyk, M.; Strek, W. The impact of shell host $\left(\mathrm{NaYF}_{4} / \mathrm{CaF}_{2}\right)$ and shell deposition methods on the up-conversion enhancement in $\mathrm{Tb}^{3+}, \mathrm{Yb}^{3+}$ codoped colloidal $\alpha-\mathrm{NaYF}_{4}$ core-shell nanoparticles. Nanoscale 2014, 6, 1855-1864. [CrossRef] [PubMed]

50. Wang, Y.F.; Sun, L.D.; Xiao, J.W.; Feng, W.; Zhou, J.C.; Shen, J.; Yan, C.H. Rare-earth Nanoparticles with enhanced upconverison emission and suppressed rare-earth-ion leakage. Chem. Eur. J. 2012, 18, 5558-5564. [CrossRef] [PubMed]

51. Chen, G.; Ohulchanskyy, T.Y.; Kumar, R.; Ågren, H.; Prasad, P.N. Ultrasmall monodisperse $\mathrm{NaYF}_{4}: \mathrm{Yb}^{3+} / \mathrm{Tm}^{3+}$ nanocrystals with enhanced near-infrared to near-infrared upconversion photoluminescence. ACS Nano 2010, 4, 3163-3168. [CrossRef] [PubMed]

52. Nadort, A.; Zhao, J.B.; Goldys, E.M. Lanthanide upconversion luminescence at the nanoscale: Fundamentals and optical properties. Nanoscale 2016, 8, 13099-13130. [CrossRef] [PubMed]

53. Wang, X.; Zhuang, J.; Peng, Q.; Li, Y.D. Heavy equipment operator training via virtual modeling technologies. Nature 2005, 437, 121-124. [CrossRef] [PubMed]

(C) 2017 by the authors; licensee MDPI, Basel, Switzerland. This article is an open access article distributed under the terms and conditions of the Creative Commons Attribution (CC BY) license (http:/ / creativecommons.org/licenses/by/4.0/). 